\title{
PENGARUH KETINGGIAN TEMPAT DAN CURAH HUJAN PADA PENYAKIT DIARE (STUDI KASUS: KABUPATEN BOGOR)
}

\author{
THE INFLUENCE OF ALTITUDE AND MONTHLY RAINFALL TO DIARRHEAL DISEASE \\ INCIDENCE RATE (CASE STUDY: BOGOR REGENCY)
}

\author{
Muhammad Syafei dan Rini Hidayati* \\ Departemen Geofisika dan Meteorologi, \\ Gedung FMIPA, Jl. Meranti Wing 19 Lv.4 Kampus IPB Darmaga, Bogor 16680 \\ * Corresponding author, email: rinihid@yahoo.com \\ Penyerahan Naskah: 10 November 2013 \\ Diterima untuk diterbitkan: 2 Mei 2014
}

\begin{abstract}
This study aimed to determine the effect of altitude and rainfall on the incidence of disease (IR ) diarrhea, and to obtain threshold values of rainfall that often cause diarrhea. Determination category of normal rate of diarrhea IR is based on diarrhea IR by DINKES Bogor in the amount of 20-25/1000 population per year, while the determination of precipitation category is based on consideration of Oldeman climate classification. The results showed that there were two districts with very high levels of vulnerability i.e. Cisarua and Cijeruk, while the other regions only at a moderate level. The negative influence of altitude (or positive influence of temperature) on the IR will be evident if the analysis is separated between in the highlands (> $600 \mathrm{asl}$ ) and the lowlands (<600 asl). This influence is significant, especially at altitudes above 600 meters above sea level. The correlation of the precipitation is significant negative linear to the incidence of diarrhea in the district Cisarua, Cibinong, Jonggol, and Jasinga. In districts Cibinong, Jonggol, and Jasinga, precipitation should be anticipated in the range of 100-200 mm/month, where moderate IR often occurs, while in the district Cisarua, is in the range of precipitation $300-400 \mathrm{~mm} / \mathrm{month}$, where high IR often occurs.
\end{abstract}

Keywords: incidence rate, IR category, precipitation, precipitation category, the level of vulnerability

Sitasi: Syafei M. dan Hidayati R. 2014. Pengaruh ketinggian tempat dan curah hujan pada penyakit diare (studi kasus: Kabupaten Bogor). J Agromet Indonesia. 28(1):33-39.

\section{PENDAHULUAN}

Diare merupakan penyakit yang dapat ditularkan oleh vektor (vector born disease), air dan makanan (water and food born disease). Sumber patogen pada penyakit diare berasal dari sampah, kotoran manusia dan hewan, serta bahan organik yang membusuk secara alamiah. Patogen menular pada manusia secara tidak langsung melalui transmisi oral. Transmisi dapat terjadi langsung melalui tangan yang kotor, terbawa lalat, air permukaan, maupun makanan (KEMENKES, 2011).

Di negara berkembang, sumber air bersih merupakan salah satu kebutuhan utama bagi masyarakat. Salah satu faktor penyebab penyakit diare adalah ketersediaan air bersih yang kurang (Singh et al., 2001). Cuaca merupakan salah satu faktor yang berperan dalam penularan penyakit, termasuk diare (Bennet et al., 2012). Musim hujan dengan adanya cemaran air oleh aliran permukaan dan musim kemarau dengan masalah kekurangan air merupakan kondisi potensial yang dapat menyebabkan penyakit diare.

Di Indonesia dari tahun 2000 hingga 2010, kejadian diare terus mengalami peningkatan. Pada tahun 2010 tercatat terjadi 411/1000 penduduk dan terjadi KLB diare di 33 kecamatan dengan jumlah penderita 4.204 dengan kematian 73 orang (CFR 1,74\%.). Kejadian Luar Biasa (KLB) diare juga masih sering terjadi, dengan case fatality rate (CFR) yang masih tinggi (KEMENKES, 2011). Di Kabupaten Bogor pada tahun 2010, angka kejadian diare tinggi, di atas $31 / 1000$ penduduk pertahun (standar 20-25/1000 penduduk pertahun). Pada saat 
tersebut, terjadi Kejadian Luar Biasa (KLB) diare di Kecamatan Megamendung dengan jumlah kasus diare 110 orang dengan kematian dua orang dan case fatality rate (CFR) 1,82\%. KLB diare menimbulkan jumlah penderita dan kematian yang besar, terutama disebabkan infeksi keracunan makanan, sanitasi yang buruk, higiene makanan dan pasokan air (DINKES, 2010).

Penelitian yang dilakukan Lapan (2009) menunjukkan terdapat hubungan antara organisme yang dapat menyebabkan penyakit seperti E.Coli dengan pola hujan. Dalam penelitian Kelly-Hole et al. (2007) di Vietnam menemukan bahwa populasi bakteri yang menyebabkan penyakit saluran pencernaan ini mengikuti pola musim. Penelitian Checkley et al. (2000) juga menunjukkan pola penyakit diare mengikuti pola musim.

Berdasarkan dugaan, terdapat hubungan antara ketinggian tempat dan kondisi iklim terhadap angka kejadian penyakit diare, sehingga diperlukan analisis terkait penentuan ambang batas kondisi iklim yang mendukung angka kejadian penyakit Diare tinggi. Penelitian ini bertujuan untuk mengetahui pengaruh ketinggian tempat dan curah hujan terhadap angka kejadian penyakit (IR) diare, dan memperoleh nilai ambang batas curah hujan yang sering menimbulkan kasus diare.

\section{METODE PENELITIAN}

\section{Alat dan Bahan}

Data yang digunakan adalah:

a. Data jumlah kasus diare di Kabupaten Bogor tahun 2004 sampai 2013 (Sumber: Unit Surveilan Epidemiologi Dinas Kesehatan Kabupaten Bogor),

b. Data iklim (curah hujan dan suhu udara) Kabupaten Bogor tahun 2004 sampai 2013 (Sumber: BMKG dan PSDA Bogor),

c. Demografi Kabupaten Bogor (Sumber: Badan Pusat Statistik Kabupaten Bogor (2013)),

d. Data ketinggian tempat (Sumber: Citra satelit SRTM DEM 90).

\section{Pengamatan Penyakit Diare}

Jumlah kasus diare dalam penelitian ini merupakan data sekunder yang diperoleh dari unit surveilan epidemiologi Dinas Kesehatan Kabupaten Bogor. Data ini diperoleh dari puskesmas-puskesmas yang terdapat di wilayah Kabupaten Bogor dan survei langsung ke masyarakat oleh Surveilan. Data diare yang digunakan merupakan data bulanan di setiap kecamatan dari hasil penjumlahan kasus diare di puskesmas-puskesmas yang ada di kecamatan tersebut.

\section{Penentuan Angka Kejadian Penyakit}

Angka kejadian penyakit (IR) diare ditentukan berdasarkan persamaan berikut:

$$
\mathrm{IR}=\frac{\text { Jumlah Kejadian Diare }}{\text { Jumlah Penduduk }} \times 1000
$$

\section{Pengaruh Ketinggian Terhadap Diare}

Ketinggian tempat diperoleh dengan analisis citra satelit SRTM DEM 90. Dari data citra DEM 90, diturunkan menjadi data ketinggian wilayah pada setiap kecamatan kajian. Data ketinggian wilayah kecamatan kemudian dirata-ratakan menggunakan pembobot luas wilayah. Pengaruh ketinggian tempat yang menggambarkan pengaruh suhu dianalisis berdasarkan perbandingan antara rata-rata ketinggian terhadap rata-rata IR tiap kecamatan.

\section{Penentuan Tingkat Kerentanan Wilayah}

Tingkat kerentanan wilayah dibagi menjadi empat kategori kerentanan, yaitu kategori kerentanan rendah, sedang, agak tinggi, dan tinggi. Kisaran nilai IR di setiap kategori kerentanan diturunkan berdasarkan informasi kisaran IR normal menurut DINKES Kabupaten Bogor, yaitu nilai normal IR sebesar 20-25/1000 penduduk per tahun (DEPKES, 2012). Penentuan nilai IR kecamatan rata-rata tahunan dilakukan dengan menjumlahkan IR bulanan dari bulan Januari hingga Desember, kemudian merata-ratakan jumlah IR tahunan tersebut selama 10 tahun (2004-2013). Penentuan nilai IR tahunan ini dilakukan di tiap kecamatan kajian. Data IR tersebut kemudian divisualisasikan dalam bentuk peta.

\section{Korelasi dan Variasi Curah Hujan terhadap Diare}

Nilai IR dan curah hujan dihitung sebagai ratarata bulanan selama 10 tahun (2004-2013). Penentuan ada atau tidak ada pengaruh hujan terhadap IR Diare ditentukan berdasarkan nilai koefisien korelasi (r) dan nilai uji nyata p. Variasi curah hujan dan pengaruhnya terhadap variasi IR diare dianalisis berdasarkan plot data selama 10 tahun (2004-2013) di tiap kecamatan.

\section{Penentuan Karakteristik Kondisi Iklim (Curah Hujan) terhadap Diare}

Penentuan karakteristik kondisi curah hujan dan pengaruhnya terhadap angka kejadian penyakit dilakukan dengan membagi curah hujan ke dalam beberapa kategori. Selanjutnya dilihat sebaran frekuensi IR pada setiap kategori curah hujan. 


\section{HASIL DAN PEMBAHASAN}

\section{Pengaruh Ketinggian terhadap Penyakit Diare}

Kabupaten Bogor terletak diantara $6^{\circ} 19^{\prime}$ $6^{\circ} 47^{\prime}$ LS dan $106^{\circ} 21^{\prime}-107^{\circ} 13^{\prime}$ BT dengan ketinggian tempat berkisar antara $15 \mathrm{mdpl}$ pada daratan di bagian utara hingga $2.500 \mathrm{mdpl}$ pada puncak gunung di bagian selatan. Tipe morfologi wilayah bervariasi, sekitar $29 \%$ berada pada ketinggian $15-100$ mdpl, $43 \%$ berada pada ketinggian 100-500 mdpl, 19\% berada pada ketinggian 500-1.000 mdpl, 8\% berada pada ketinggian 1.000-2.000 mdpl, dan 1\% berada pada ketinggian 2.000-2.500 mdpl.

Perbedaan ketinggian antara satu wilayah dengan wilayah yang lain dapat menunjukkan perbedaan suhu antar wilayah tersebut. WHO (2004) dalam Kolstad dan Johansson (2011) mengestimasi perubahan suhu sebesar $1^{\circ} \mathrm{C}$ menyebabkan peningkatan kasus diare sebesar $0-10 \%$. Kovats et al. (2003) mendapatkan adanya korelasi positif antara kenaikan suhu dan perkembangan salmonella, bakteri yang menyebabkan diare. Dengan demikian jika suhu rendah perkembangan bakteri salmonella akan rendah, sehingga kecenderungan kasus diare juga rendah.

Jika dilihat secara rata-rata, hasil analisis angka kejadian penyakit Diare di Kabupaten Bogor menunjukkan kejadian yang berlawanan dengan hasil penelitian yang dilakukakan oleh Kolstad dan Johansson (2011) dan Kovats et al. (2003). Tren angka kejadian diare bertambah dengan peningkatan ketinggian tempat, meskipun suhu berkurang. Akan tetapi, jika pola kasus dipisahkan antara kecamatan yang memiliki ketinggian kurang dan lebih dari 600 mdpl maka akan terlihat pola penurunan kasus dengan bertambahnya ketinggian tempat (Tabel 1 dan Gambar 1).

Tabel 1. Kepadatan penduduk dan rataan IR bulanan tingkat Kecamatan.

\begin{tabular}{lccc}
\hline Kecamatan & $\begin{array}{c}\text { Rataan h } \\
\text { (mdpl) }\end{array}$ & $\begin{array}{c}\text { Kepadatan } \\
\text { Penduduk }\end{array}$ & $\begin{array}{c}\text { Rataan } \\
\text { IR }\end{array}$ \\
\hline Cisarua & 1.174 & 1.594 & 3,80 \\
Cijeruk & 635 & 913 & 4,57 \\
Leuwiliang & 515 & 987 & 2,01 \\
Cigudeg & 320 & 676 & 2,24 \\
Ciampea & 205 & 4.709 & 2,40 \\
Cibinong & 200 & 6.173 & 2,19 \\
Jonggol & 187 & 847 & 1,92 \\
Jasinga & 130 & 779 & 2,99 \\
Cileungsi & 118 & 2.555 & 2,12 \\
\hline
\end{tabular}

Apabila analisis pengaruh ketinggian dipisahkan antara ketinggian $>600$ mdpl dan $<600$ mdpl, pengaruh ketinggian/suhu terhadap IR Diare akan terdeteksi. Di atas $600 \mathrm{mdpl}$, Kecamatan Cisarua dengan suhu udara yang relatif lebih rendah, jumlah kasus diare juga lebih rendah dibandingkan dengan jumlah kasus di Kecamatan Cijeruk. Pada ketinggian <600 mdpl tren kasus menunjukkan pola yang hampir sama meskipun dengan intensitas yang berbeda. Pengaruh suhu udara pada perkembangan patogen penyebab Diare, terutama pada ketinggian $>600$ mdpl diduga menyebabkan kondisi ini, yaitu semakin tinggi tempat IR Diare makin berkurang.

Sumber air pada ketinggian $>600$ mdpl lebih banyak yang berasal dari sumber mata air permukaan (PDAM Kab. Bogor, 2011). Berdasarkan data PDAM Kab. Bogor (2011) pasokan sumber air bersih pada Kecamatan Cisarua dan Cijeruk relatif rendah, yakni 20 L/detik di Kecamatan Cisarua dan 10 L/detik di Kecamatan Cijeruk. Air dari sumber air di dataran tinggi dan curam biasanya disalurkan melalui pipa-pipa yang mengalir dari rumah ke rumah, sehingga air sangat mudah tercemar oleh limbah. Pada ketinggian <600 mdpl, lebih banyak mendapat pelayanan air dari PDAM dengan pengolahan lengkap atau berasal dari sumur bor yang kebersihannya lebih terjamin (PDAM Kab. Bogor 2011). Rata-rata pasokan air bersih oleh PDAM sebesar lebih dari $20 \mathrm{~L} /$ detik, angka ini lebih besar dibandingkan kecamatan di wilayah ketinggian $>600 \mathrm{mdpl}$. Kondisi ini diduga menjadi penyebab IR di wilayah $>600$ mdpl lebih tinggi daripada IR pada wilayah $600 \mathrm{mdpl}$.

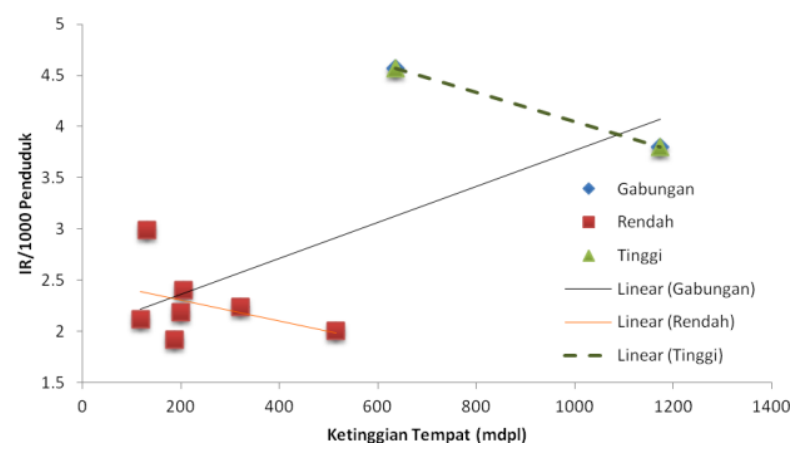

Gambar 1. Tren hubungan antara ketinggian tempat dengan IR diare di Kabupaten Bogor periode tahun 2004-2013.

Pada ketinggian kurang dari 600 mdpl jumlah kasus di Kecamatan Cibinong, Ciampea, dan Cileungsi menunjukkan nilai IR yang paling tinggi. Kecamatan tersebut memiliki kepadatan penduduk yang paling padat yaitu sebesar $6.173 / \mathrm{km}^{2}$; $4.709 / \mathrm{km}^{2} ;$ dan $2.555 / \mathrm{km}^{2}$ secara berturutan dibandingkan kecamatan lain yang kepadatan penduduknya kurang dari $1.000 / \mathrm{km}^{2}$ (Tabel 1). 
Kepadatan penduduk yang tinggi menyebabkan kondisi sanitasi lingkungan menjadi buruk, sehingga lebih besar kemungkinan terjadi penyakit diare. Menurut Achmadi (2008) kepadatan penduduk merupakan persemaian subur bagi virus. Sebuah wilayah yang padat penduduk akan lebih mudah terjadi penularan dan perkembangbiakan sehingga menjadi lebih rentan bagi penyebaran penyakit menular seperti penyakit diare (Achmadi, 2008). Diare yang disebabkan oleh infeksi sebesar 90\% kejadian, oleh infeksi virus sebesar $70 \%$ (Rotavirus dan Adenovirus) dan bakteri 8,4\%. Rotavirus menyebabkan peningkatan kasus diare melalui makanan dan air (KEMENKES, 2011).

\section{Perbandingan Tingkat Kerentanan antar Wilayah Kecamatan}

Angka kejadian normal diare di Kabupaten Bogor adalah sebesar 20-25/1000 penduduk/tahun (DINKES, 2010). Berdasarkan data tersebut, maka tingkat kerentanan IR wilayah dibagi menjadi empat kategori yaitu kategori rendah $(<20)$, sedang $(20$ 30), tinggi (30-40), dan sangat tinggi (>40). Kategori sedang menunjukkan angka kejadian diare normal, kategori (kerentanan) rendah menunjukkan kejadian diare di bawah normal, sedangkan kerentanan tinggi dan sangat tinggi menunjukkan kejadian diare di atas normal.

Wilayah kabupaten Bogor sebagian besar merupakan wilayah pedesaan, sebagian besar penduduk berpenghasilan rendah dan tinggal jauh dari pelayanan kesehatan (Bappenas, 2010). Hal ini mungkin ikut berperan menyebabkan tidak adanya kecamatan yang termasuk dalam kerentanan rendah (Tabel 2).

Kecamatan Cisarua dan Cijeruk sebagian daerahnya terletak di dataran tinggi dan curam. Sumber air pada ketinggian >600 mdpl lebih banyak berasal dari sumber air permukaan dari mata air (PDAM Kab. Bogor, 2011). Minimnya pasokan air bersih yang minim dapat mengakibatkan kejadian diare yang tinggi. Selain karena sumber air, kedua kecamatan ini juga menerima curah hujan bulanan yang cukup tinggi, sehingga peluang kejadian limpasan permukaan juga tinggi. Hampir setiap bulan angka kejadian penyakit diare sangat tinggi.

Kecamatan dengan nilai rata-rata IR tahunan terendah yaitu kecamatan Jonggol, dengan IR sebesar 23,00/1000 penduduk dengan tingkat kerentanan sedang. Curah hujan tahunan Kecamatan Jonggol (2.109 mm/tahun) termasuk rendah bila dibandingkan dengan Kecamatan lain yang mengakibatkan peluang kejadian banjir di kecamatan ini kecil, sehingga air bersih di kecamatan ini jarang tercemar oleh banjir. Selain itu Kecamatan Jonggol juga termasuk dalam kecamatan yang dijadikan sebagai tempat pengembangan prasarana sumber air permukaan untuk air bersih di Kabupaten Bogor. Ketersediaan air bersih yang cukup memadai menyebabkan tingkat kerawanan penyakit diare di kecamatan ini kecil (Pemkab Bogor, 2014).

Kabupaten Bogor termasuk wilayah dengan cakupan air bersih kurang memadai. Mutu air hasil analisis Badan Pengendalian Hidup Daerah terhadap beberapa sungai yang melintas di Kabupaten Bogor, seperti Sungai Ciliwung, Sungai Cisadane, dan sungai Cileungsi menunjukkan level tercemar berat (Level D) (Pemkab Bogor, 2014). Selain Faktor cuaca, ketersediaan air bersih yang kurang juga merupakan faktor yang ikut berpengaruh. Kurangnya cakupan air bersih merupakan salah satu faktor penting dalam kejadian penyakit diare (Singh et al., 2001).

Tabel 2. Tingkat kerentanan wilayah berdasarkan rata-rata IR tahunan beberapa kecamatan di Kabupaten Bogor tahun 2004-2013.

\begin{tabular}{lcc}
\hline Kecamatan & $\begin{array}{c}\text { Rata-Rata IR } \\
\text { Tahunan }\end{array}$ & $\begin{array}{c}\text { Tingkat } \\
\text { Kerentanan }\end{array}$ \\
\hline Cisarua & 45,64 & Sangat Tinggi \\
Cijeruk & 54,84 & Sangat Tinggi \\
Jasinga & 35,89 & Tinggi \\
Cigudeg & 26,91 & Sedang \\
Ciampea & 28,75 & Sedang \\
Cibinong & 26,28 & Sedang \\
Jonggol & 23,00 & Sedang \\
Leuwiliang & 24,07 & Sedang \\
Cileungsi & 25,49 & Sedang \\
\hline
\end{tabular}

Kejadian diare juga sangat dipengaruhi oleh akses terhadap sanitasi lingkungan. Beberapa faktor yang berkorelasi positif dengan kejadian kasus diare yaitu sistem pembuangan sampah yang kurang baik (Bruyn, 2000). Sampah yang banyak dapat menyebabkan sanitasi lingkungan menjadi buruk. Jumlah penduduk kabupaten Bogor pada tahun 2013 yang mencapai lebih dari 5 juta penduduk terutama kecamatan Cibinong, Cileungsi dan Jasinga diestimasi menghasilkan jumlah timbulan sampah mencapai $10.290 \mathrm{~m}^{3} /$ hari sedangkan kapasitas jumlah sampah yang terangkut hanya mampu sebesar $1.050 \mathrm{~m} 3 /$ hari. (Pemkab Bogor, 2014) sehingga terlihat tingkat kerentanan masing-masing kecamatan dominan berada pada tingkat sedang.

\section{Korelasi Curah Hujan Bulanan terhadap Penyakit Diare}

Faktor cuaca merupakan salah satu faktor yang berperan dalam penularan penyakit menular termasuk diare (Bennet et al., 2012). Selain suhu, curah hujan juga diduga berpengaruh terhadap IR 
Diare melalui kecukupan dan kebersihan/kesehatan air. Curah hujan yang tinggi dapat menyebabkan banjir di suatu wilayah sehingga akses air di wilayah tersebut menjadi tercemar akibat banjir, sedangkan apabila curah hujan rendah pasokan air bersih kurang yang berdampak buruk pada sanitasi makanan dan lingkungan. Ketersediaan air bersih dan kondisi sanitasi suatu daerah dipengaruhi oleh ketersediaan sumber daya air, potensi banjir, dan potensi kekeringan (Bappenas, 2010).

Dari hasil analisis korelasi diperoleh hampir di semua kecamatan kecuali Cijeruk, IR diare berkorelasi linear negatif dengan curah hujan bulanan. Terdapat empat kecamatan yang curah hujannya berkorelasi nyata dengan kejadian diare, yaitu Kecamatan Cisarua, Cibinong, Jonggol, dan Jasinga (Tabel 3). Keempat kecamatan tersebut masing-masing memiliki nilai koefisien korelasi $(r)$ sebesar -0,851; -0,558; -0,536 dan -0,709 dengan nilai uji $p<0,10$. Hal ini berarti apabila curah hujan tinggi maka angka kejadian penyakit diare mengalami penurunan dengan pengaruh nyata < 0,10. Di kecamatan Cijeruk, Leuwiliang, Cigudeg, Ciampea dan Cileungsi korelasi antara curah hujan dengan kejadian penyakit diare tidak nyata dengan dari nilai koefisien korelasi dan nilai uji $p$ (Tabel 3).

\section{Karakteristik Curah Hujan yang Berpengaruh terhadap Penyakit Diare}

Berdasarkan hubungan antara curah hujan dan kejadian penyakit diare di Kecamatan kajian, terlihat jelas korelasi linear negatif hampir di semua
Kecamatan kajian, dimana kejadian diare tinggi terjadi pada periode curah hujan rendah dan sebaliknya. Dari plot angka kejadian diare dengan curah hujan bulanan, pada bulan-bulan curah hujan rendah, kejadian diare seringkali mengalami peningkatan, dan pada bulan basah kejadian diare tidak konsisten rendah. Terdapat empat kecamatan yang memiliki korelasi nyata negatif antara curah hujan dengan IR diare, yaitu kecamatan Cisarua, Cibinong, Jonggol, dan Jasinga. Tren IR yang terbentuk di empat kecamatan ini lebih jelas terjadi peningkatan kejadian diare terjadi pada bulan dengan curah hujan rendah, sedangkan di kecamatan lain tren IR lebih beragam (Gambar 2).

Tabel 3. Koefisien korelasi antara curah hujan bulanan IR dengan diare pada kecamatan terpilih di Bogor.

\begin{tabular}{lcc}
\hline Kecamatan & $\begin{array}{c}\text { r(koefisien } \\
\text { korelasi) }\end{array}$ & $\boldsymbol{p}$-value \\
\hline Cisarua & $-0,851$ & 0,000 \\
Cijeruk & 0,054 & 0,866 \\
Leuwiliang & $-0,335$ & 0,287 \\
Cigudeg & $-0,301$ & 0,342 \\
Ciampea & $-0,335$ & 0,287 \\
Cibinong & $-0,558$ & 0,059 \\
Jonggol & $-0,536$ & 0,073 \\
Jasinga & $-0,709$ & 0,010 \\
Cileungsi & $-0,085$ & 0,793 \\
\hline
\end{tabular}
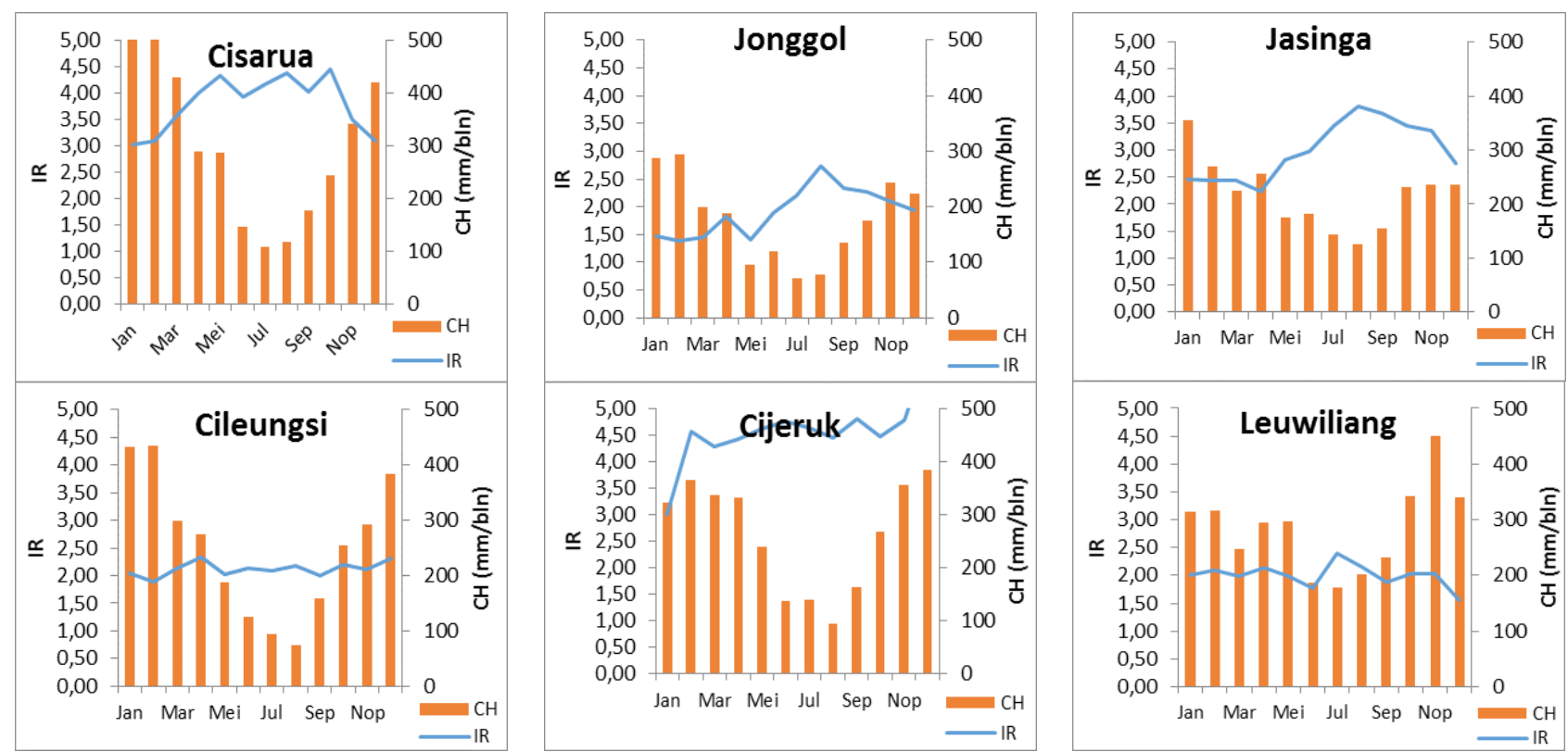

Gambar 2. Curah hujan bulanan dan IR di enam kecamatan kajian. 
(a)

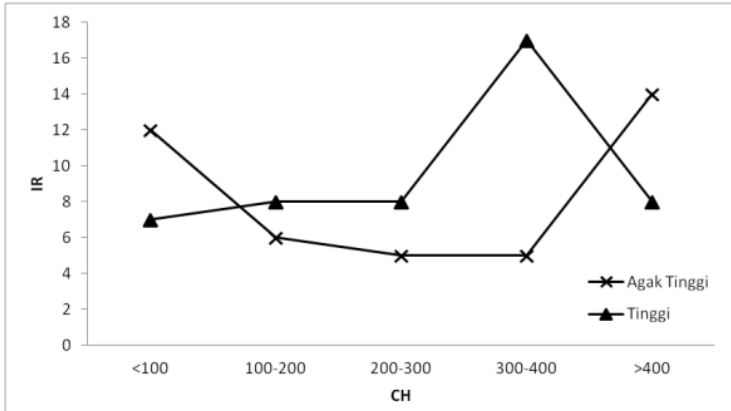

(c)

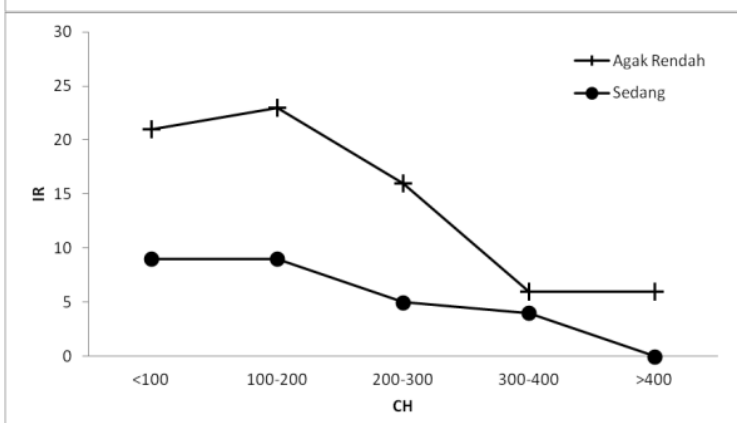

(b)

(d)

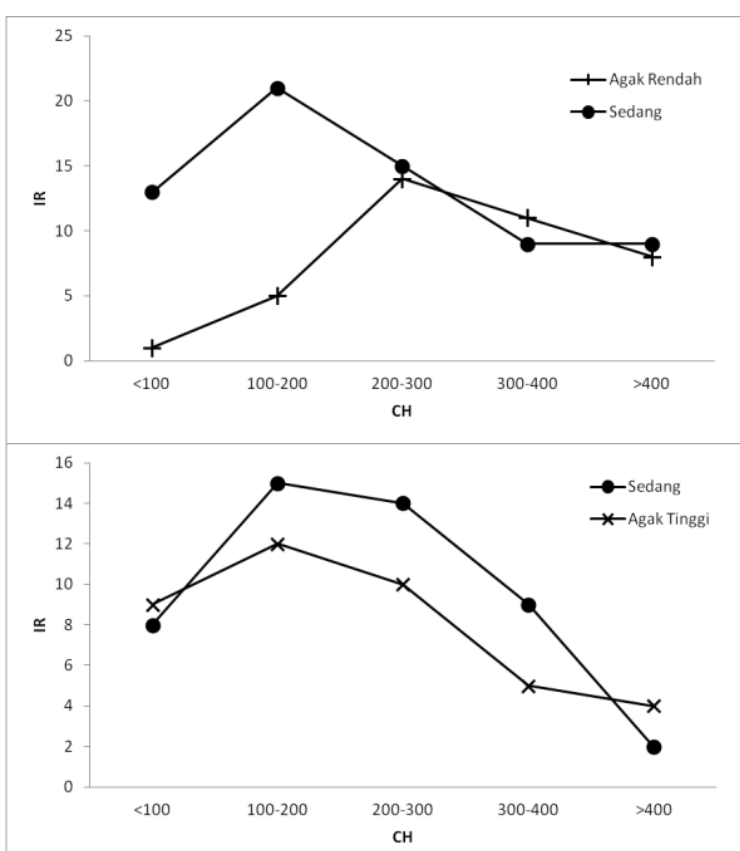

Gambar 3. Pola IR terhadap kategori curah hujan kecamatan Cisarua (a), Cibinong (b), Jonggol (c), dan Jasinga (d) tahun 2004-2013.

Analisis curah hujan lebih lanjut, data curah hujan dibuat dalam lima kategori yaitu curah hujan dengan kisaran $<100 \mathrm{~mm}$ (rendah), 100-200 $\mathrm{mm}$ (agak rendah), 200-300 mm (sedang), 300-400 mm (agak tinggi), dan $>400 \mathrm{~mm}$ (tinggi), dimaksudkan untuk mengetahui kisaran curah hujan yang menyebabkan tinggi atau rendah kejadian diare. Pengkategorian curah hujan ini dilakukan mempertimbangkan batasan curah hujan pada klasifikasi iklim Oldeman dimana curah hujan $<100 \mathrm{~mm} / \mathrm{bulan}$ termasuk curah hujan rendah atau bulan kering dan $>200 \mathrm{~mm} /$ bulan termasuk curah hujan tinggi atau bulan basah, yang dianggap lebih sesuai untuk wilayah Kabupaten Bogor dengan curah hujan tinggi. IR yang diplotkan bersama curah hujan berkatagori adalah IR dengan frekuensi kejadian tertinggi pada wilayah kecamatan tersebut (Gambar $3)$.

Di Kecamatan Cisarua, frekuensi kategori IR terbanyak adalah kategori agak tinggi dan tinggi. Frekuensi kategori IR agak tinggi paling sering terjadi pada saat kondisi curah hujan rendah $(<100$ $\mathrm{mm} /$ bulan) dan curah hujan tinggi ( $>400 \mathrm{~mm} / \mathrm{bulan})$, sedangkan frekuensi kategori IR tinggi paling sering terjadi pada kondisi curah hujan agak tinggi (300$400 \mathrm{~mm} /$ bulan).

Di Kecamatan Cibinong dan Jonggol, frekuensi kategori IR terbanyak yaitu kategori agak rendah dan sedang, dengan kata lain jumlah penderita diare di Kecamatan Cibinong dan Jonggol menunjukkan angka rata-rata yang tidak tinggi sehingga kejadian luar biasa diare di kedua kecamatan ini tidak menjadi masalah yang sering dihadapi. Di Kecamatan Cibinong, frekuensi kategori IR agak rendah menunjukkan bahwa kejadian diare kategori ini paling sering terjadi pada saat kondisi curah hujan rendah (100-200 mm/bulan), sedangkan frekuensi IR pada kategori sedang paling sering terjadi pada kondisi curah hujan sedang (200-300 $\mathrm{mm} /$ bulan). Di Kecamatan Jonggol frekuensi kategori IR agak rendah dan sedang paling sering terjadi pada saat kondisi curah hujan rendah (100$200 \mathrm{~mm} /$ bulan).

Di Kecamatan Jasinga, frekuensi kategori IR terbanyak adalah kategori sedang dan agak tinggi. Frekuensi kategori IR sedang dan agak tinggi paling sering terjadi pada saat kondisi curah hujan rendah (100-200 mm/bulan). Di empat kecamatan yang dikaji diketahui kejadian diare tinggi dominan terjadi pada curah hujan rendah, sedangkan di kecamatan Cisarua, kejadian diare tinggi bisa terjadi pada kondisi curah hujan rendah dan tinggi. Bennet et al. (2012) menjelaskan bahwa musim penghujan dengan terjadinya banjir merupakan puncak terjadinya penyakit diare serta musim kemarau juga menunjukkan adanya hubungan dengan kejadian penyakit diare.

Karakteristik curah hujan yang menyebabkan kategori IR diare dominan, berbeda antar kecamatan, sehingga belum dapat dilihat pola umumnya. Meskipun secara umum berkorelasi negatif, tetapi IR agak redah dan sedang sering terjadi pada $\mathrm{CH}$ antara 100-200 mm dan khusus di Cisarua, IR tinggi terbanyak terjadi pada $\mathrm{CH} 300-400 \mathrm{~mm}$. Jumlah hari hujan diduga juga merupakan unsur iklim penting dalam proses perkembangan jumlah kasus diare, tetapi karena data hari hujan tidak tersedia maka dalam analisis ini data hari hujan tidak dianalisis. Data hujan harian, diduga akan memberikan hasil analisis yang lebih tajam 
dibandingkan jika menggunakan data hujan bulanan karena perkembangan bakteri dan virus sangat tergantung dari kondisi iklim harian suatu wilayah. Vektor penyebab penyakit diare juga perkembangannya sangat bergantung pada kondisi iklim, terutama suhu harian.

\section{KESIMPULAN}

Pengaruh positif suhu atau pengaruh negatif ketinggian terhadap IR akan nyata jika analisis dipisahkan antara IR di dataran tinggi dan di dataran rendah. Pengaruh ini nyata, terutama pada ketinggian di atas 600 mdpl. Selain ketinggian tempat, penerimaan curah hujan wilayah juga berpengaruh nyata terhadap angka kejadian diare di 4 kecamatan, yaitu Kecamatan Cisarua, Cibinong, Jonggol, dan Jasinga dengan korelasi negatif. Korelasi curah hujan bulanan dengan IR bernilai negatif, IR tinggi pada bulan-bulan curah hujan rendah. Karakteristik curah hujan yang menyebabkan kategori IR diare dominan berbeda antar kecamatan, sehingga belum dapat dilihat polanya secara umum. Meskipun secara umum hujan dan IR bulanan berkorelasi negatif, tetapi dari frekuensi kejadian, IR agak redah dan sedang sering terjadi pada $\mathrm{CH}$ antara $100-200 \mathrm{~mm}$ dan khusus di Cisarua, IR tinggi terbanyak terjadi pada $\mathrm{CH} 300$ $400 \mathrm{~mm}$.

\section{DAFTAR PUSTAKA}

Achmadi U.F. 2008. Manajemen Penyakit Berbasis Wilayah. Jakarta (ID): UI Pr.

[Bappenas] Badan Perencanaan Pembangunan Nasional. 2010. Indonesia Climate Change Sectoral Roadmap (ICCSR) Sektor Kesehatan. Jakarta (ID): Bappenas.

Bennet A., Leonardo D.E., Robert H.G., Vitaliano C., Caryn, Lilia C., Andres G.L., Jonathan P., Cesar C., Charles R.S. and William C. 2012. Effects of the 1997-1998 El Niño episode on community rates of diarrhea. American J Public Health. 102(7):63-69.

[BOM] Australian Government Bureau of Meteorology. 2008. Southern Oscillation Index (SOI). [internet]. [diacu Agustus 2014]. Tersedia dari http://www.bom.gov.au.

[BPS] Badan Pusat Statistik Kabupaten Bogor. 2013. Kabupaten Bogor Dalam Angka 2013. Bogor: BPS.

Bruyn D.G. 2000. Infectious disease: Diarrhea. Western J Medicine. 177:409-412.

Checkley W., Epstein L.D., Gilman R.H., Figueroa D., Cama R.I. and Patz J.A. 2000. Effects of El Niño and ambient temperature on hospital admissions for diarrhoeal diseases in Peru. The Lancet. 355:442-450.

[DINKES] Dinas Kesehatan Kabupaten Bogor. 2010. Profil Kesehatan Kabupaten Bogor. Bogor: DINKES.

Kelly-Hole L.A., Alonso W.J., Thiem V.D., Canh D.G., Anh D.C., Lee H. and Miller M.A. 2007. Temporal trends and climatic factors associated bacterial enteric diseases in Indonesia 1991-2001. Environmental Health Perspectives. 116:7-12.

[KEMENKES] Kementerian Kesehatan. 2011. Situasi Diare di Indonesia. Buletin Jendela dan Informasi Kesehatan 2: 1.

Kolstad E., Johansson W. and Arne K. 2011. Uncertainties associated with quantifying climate change impacts on human health: A case study for diarrhea. Enviromental Heath Perspective. 199:299-305.

Kovats R.S., Bouma M.J., Hajat S., Worrall E. and Haines A. 2003. El Niño and Health. The Lancet. 362:1481-1489.

Lapan. 2009. Perubahan iklim dan dampaknya pada kesehatan. [internet].[diacu Juli 2014]. Tersedia dari http://dirgantara.lapan.or.id.

[PDAM Kab. Bogor] Perusahaan Daerah Air Minum Kabupaten Bogor. 2011. Lokasi Pengolahan Air. [internet]. [Juli 2014]. Tersedia dari http://www.pdamkabbogor.co.id/lokasi_pengolaha n.php

[Pemkab Bogor] Pemerintah Daerah Kabupaten Bogor. 2014. Rencana Pembangunan Jangka Menengah Daerah (RPJMD) Kabupaten Bogor Tahun 20132018. Bogor: Pemkab Bogor.

Singh R.B.K., Hales S., Wet N.D., Raj R., Heamden M. and Weinstein P. 2001. The influence of climate variation and change on diarrheal disease in the pacific islands. $J$ Environmental Health Perspectives. 109(2):155-159. 